\title{
Extensions of closed convex processes
}

\author{
A. R. BAIAS and T. TRIF
}

\section{ABSTRACT.}

In this paper we provide some norm preserving extension results for real valued closed convex processes. As a consequence, we characterize afterwards, the elements of best approximation in normed linear spaces by elements of closed convex cones using closed convex processes.

\section{REFERENCES}

[1] Abreu, J. and Etcheberry, A., Hahn-Banach and Banach-Steinhaus theorems for convex processes, Period. Math. Hung., 20 (1989), No. 4, 289-297

[2] Aubin, J. P. and Frankowska, H., Set-Valued Analysis, Birkhäuser, Boston, 1990

[3] Banach, S., Théorie des opérations linéaires, Monografje Matematyczne, 1, Warszawa, 1932

[4] Boţ, R. I., Grad, S.-M. and Wanka, G., Duality in Vector Optimization, Springer-Verlag, Berlin, 2009

[5] Cobzaş, Ş. and Mustăţa, C., Norm preserving extension of convex Lipschitz functions, J. Approx. Theory, 24 (1978), 555-564

[6] Cobzaş, Ş. and Mustăţa, C., Extension of Lipschitz functions and best approximation, Research on the Theory of Allure, Approximation, Convexity and Optimization (E. Popoviciu ed.), Srima Publishers, Cluj-Napoca, 1999, 3-21

[7] Edwards, R. E., Functional Analysis. Theory and Applications, Holt, Rinehart and Winston, 1965

[8] Hahn, H., Über lineare Gleichungssysteme in linearen Räumen, J. Reine Angew. Math., 157 (1927), $214-229$

[9] McShane, J. A., Extension of range of functions, Bull. Amer. Soc., 40 (1934), 837-842

[10] Rudin, W., Functional Analysis, McGraw-Hill, New-York, 1973

[11] Ruess, W., Ein Dualkegel für p-konvexe topologische lineare Räume, Geselschaft für Mathematik und Datenverarbeitung, 60 (1973)

[12] Singer, I., Best Approximation in Normed Linear Spaces by Elements of Linear Subspeces, Springer-Verlag, Berlin, 1970

BABEŞ-BOLYAI UNIVERSITY

FACULTY OF MATHEMATICS AND COMPUTER SCIENCE

Mihail Kogalniceanu 1, 400084 Cluj-Napoca, Romania

E-mail address: alina.baias@transylvania-college.ro.

E-mail address: ttrif@math.ubbcluj.ro.

Received: 09.06.2013; In revised form: 08.01.2014; Accepted: 23.04.2014

2010 Mathematics Subject Classification. 54C60, 54C20.

Key words and phrases. Closed convex process, Hahn-Banch extension theorem.

Corresponding author: Alina Baias; frateanalina@yahoo.com 